Pavlovska Svitlana,

PhD in History (military history), leading Researcher research laboratory Humanitarian Institute

National University of Defense of Ukraine named after Ivan hernyakhovsky ORCID 0000-0002-7038-8835

super-varkusha@ukr.net

Hrytsiuk Valerii, PhD in History leading researcher Military History Research Center National University of Defence of Ukraine after Ivan Cherniakhovskyi ORCID 0000-0001-9877-1900 skifwo@email.ua

\title{
FEATURES OF THE USE OF CHILDREN'S AND WOMEN'S IMAGES IN THE DEPICTION OF VICTIMS IN SOVIET PROPAGANDA MATERIALS IN THE SECOND WORLD WAR
}

The aim of the study. Identify the peculiarities of designing artistic images of women and children in agitation and propaganda Soviet production during the Second World War and representing them ideological settings and values. The methodology of the study involves the use of a set of approaches and methods that achieve the goals of the study, in particular, the analytical method, comparative, with the help of which identify the common features in the formation of imagery proparadist and agitation posters using images of women and children; typology - to find out the gradation of the main ideological types of visual images and their representational value concepts; general-historical approach, which allowed to reveal general tendencies in the functioning of the Soviet ideological apprentices during the Second World War. The scientific novelty of the work consists in the fact that for the first time the research of ideological propaganda of the Durgoi of the World War with the current tendencies of the informational and ideological confrontation, which involves exercising influence on the human psyche using a certain information product, was actualized. Conclusions. As a result of the study, it was found that during the Second World War the Red Army was one of the most common methods of demoralizing the enemy and forcing him to stop armed resistance was a campaign postcard with a strong emotional subtext. Typically, the image of victims of war - members of the families of servicemen was used. The most frequent themes for postcards that were supposed to raise the spirit of Soviet soldiers were the images of raped and killed women with children who cry near them; images of female prisoners; children behind barbed wire who beg for help. These images were intended not only to inspire the continuation of the war to a victorious end, but to serve as motivators for each Red Army in the fight against the enemy.

Key words: Second World War, Red Army, propaganda activity, ideological structures of the Red Army, posters, leaflets, victim, peculiarities of the victim's image.

Павловська Світлана Володимирівна, кандидат історичних наук, провідний науковий співробітник науково-дослідної лабораторії Гуманітарного інституту Національного університету оборони України імені Івана Черняховського; Грицюк Валерій Миколайович, кандидат історичних наук, доцент, провідний науковий співробітник Науково-дослідного Центру воєнної історії Національного університету оборони України імені Івана Черняховського

Особливості використання дитячих та жіночих образів у зображенні жертв війни в радянських пропагандистських матеріалах часів Другої світової війни

Мета дослідження. Виявити особливості конструювання художніх образів жінок і дітей на агітаційно-пропагандистській радянській продукції часів Другої світової війни та репрезентовані ними ідеологічні установки й цінності. Методологія дослідження передбачає застосування сукупності підходів і методів, що дозволяють досягнути мети дослідження, зокрема аналітичного методу, компаративного, за допомоги яких виявити спільні риси у формуванні образності пропагандистських та агітаційних плакатів із використанням образів жінок і дітей; типологізації - для з'ясування градації основних ідеологічних типів візуальних зображень та репрезентовані ними ціннісні концепти; загальноісторичних підхід, що дозволив виявити загальні тенденції у фуункціонуванні радянського ідеологічного апарату часів Другої світової війни. Наукова новизна роботи полягає у тому, що вперше актуалізовано дослідження ідеологічної пропаганди Другої світової війни із сучасними тенденціями інфоормаційного та ідеологічного протистояння, яка передбачає здійснення впливу на психіку людини з використанням певного інформаційного продукту. Висновки. У результаті проведеного дослідження встановлено, що у Червоній армії під час Другої світової війни одним з найпоширеніших способів деморалізації противника і примушення його до припинення збройного опору була агітаційна листівка із сильним емоційним підтекстом. Як правило, використовувався образ жертв війни - членів сімей військовослужбовців. Найбільш частими темами для листівок, які повинні були підняти дух радянських солдатів, були образи зґвалтованих і вбитих жінок з дітьми, які плачуть біля них; образи жінок-в'язнів; дітей за колючим дротом, які благають про допомогу. Ці образи були покликані не тільки надихати на продовження війни до переможного кінця, але й слугувати мотиваторами для кожного червоноармійця у боротьбі з ворогом.

Ключові слова: Друга світова війна, Червона армія, пропагандистська діяльність, ідеологічні структури Червоної армії, плакати, листівки, жертва, особливості образу жертви.

Павловская Светлана Владимировна, кандидат исторических наук, ведущий научный сотрудник научноисследовательской лаборатории Гуманитарного института Национального университета обороны Украины имени Ивана Черняховского; Грицюк Валерий Николаевич, кандидат исторических наук, доцент, ведущий научный сотрудник Научноисследовательского центра военной истории

Национального университету обороны Украины имени Иван Черняховского

Особенности использования детских и женских образов для изображения жертв войны в советских пропагандистских материалах времен Второй мировой войны

(C) Pavlovska S., 2019

(C) Hrytsiuk V., 2019 
Цель исследования. Выявить особенности конструирования художественных образов женщин и детей на агитационнопропагандистской советской продукциии времен Второй мировой войны и представляемые ими идеологические установки и ценности. Методология исследования предполагает применение совокупности подходов и методов, позволяющих достигнуть цели исследования, в частности аналитического метода, компаративного, с помощью которых выявить общие черты в фрормировании образности пропарадистских и агитационных плакатов с использованием образов женщин и детей; типологизациии - для выяснения градациии основных идеологических типов визуальных изображений и представляемых ими ценностных концептов; общеисторический подход, который позволил выявить общие тенденции в функционировании советского идеологического апрата времен Второй мировой войны. Научная новизна работы заключается в том, что впервые актуализировано исследование идеологической пропаганды Второй мировой войны с современными тенденциями информационного и идеологического противостояния, которая предусматривает осуществление воздействия на психику человека с использованием определенного информационного продукта. Выводы. В результате проведенного исследования установлено, что в Красной армии во время Второй мировой войны одним из самых распространенных способов деморализации противника и принуждения его к прекращению вооруженного сопротивления была агитационная листовка с сильным эмоциональным подтекстом. Как правило, использовался образ жертв войны - членов семей военнослужащих. Наиболее частыми темами для открыток, которые должны были поднять дух советских солдат, были образы изнасилованных и убитых женщин с детьми, которые плачут у них; образы женщин-заключенных; детей за колючей проволокой, которые просят о помощи. Эти образы были призваны не только вдохновлять на продолжение войны до победного конца но и служить мотиваторами для каждого красноармейца в борьбе с врагом.

Ключевые слова: Вторая мировая война, Красная армия, пропагандистская деятельность, идеологические структуры Красной армии, плакаты, открытки, жертва, особенности образа жертвы.

The purpose of the article is to study the main directions in the work on leaflets. The authors explore the artistic techniques that Soviet ideologists used to maintain the high morale of the Red Army soldiers and demoralize the enemy. Work with the visual format is characteristic of the activities of the ideological structures of all armies, which took part in military conflicts from the second half of the last century. Leaflets are still one of the most common ways to influence the psychology of the target audience. The importance of this area of research is due to the complex socio-political situation in Ukraine. To confront the enemy, it is necessary to know his methods of work, many of which have remained unchanged since the Second World War.

Introduction. In any war, it is important for the opposing sides to use a set of methods aimed at demoralizing the enemy. First of all, these are agitation and propaganda activities that envisaged the implementation of impact on the human psyche using a specially prepared information product.

During the Second World War, the ideological structures of the Red Army organized large-scale activities to create and distribute visual products. The most effective were leaflets and posters. This information product had the different target audience. This article will consider the features of creating a visual format that was aimed at the Nazis and the personnel of the Red Army. The content of Soviet leaflets, main slogans, and motivational orientation were changing throughout the Second World War, depending on the changing situation in the theaters of military operations. In the first months of the war on the territory of the USSR, the propaganda activities of the ideological structures of the Red Army bore a tinge of class struggle. In the first text leaflets, army ideologists called on the Nazis to show their class consciousness and turn their bayonets against the imperialists who unleashed an aggressive war.[1] The main was the slogan to join the workers 'and peasants' the Red Army and crush the universal imperialism together. These appeals were unsuccessful. Firstly, because Hitler and his political power were popular in Germany. Secondly, successful military campaigns and experience of victories inspired the Nazis to further seize the territories to expand the living space of Germany. Very quickly the leadership of the Main Political Administration of the Red Army realized that it was necessary to change tactics and look for other ways of influence. Military ideologists categorically lacked knowledge about the Hitlerite soldier, his mentality, and psychological vulnerability. As a result of the measures taken, in particular, the analysis of trophy documents, it was possible to draw up a psychological portrait of a serviceman of the Hitlerite army. The study of trophy diaries, letters, evidences of prisoners of war made it possible to understand the value system of a German soldier who was heavily motivated to wage war to the limit.[1]

The collapse of the plan to capture Moscow and the defeat of the Germans at Stalingrad had significantly undermined their morale. It became clear that there would be no lightning victorious advancement. Controversial opinions about their further participation in the war began to emerge among German servicemen. This had become a breeding ground for impact on the enemy. Soviet army ideologists now began to use the slogan of surrendering to save lives and return home.

It was clear that one of the most common ways to demoralize the enemy and force him to stop armed resistance was a leaflet with powerful emotional overtones. For the German soldiers, family values were fundamental to their understanding of orderly life. The most common were leaflets with the following topics:

- images of orphaned children against the background of a military funeral;

- crying women with children who received news of the death of their spouse;

- A child crying out of desperation against the background of the body of the murdered father.

Both independent drawing scenes and subjects using photos were produced. It should be noted that the use of lifestyle tunes associated with suffering of children and women has always influenced the intensification of the emotional experience about the inability to protect their family. Specialists of the Main Political Directorate of the Red Army developed 200 theses, which were grouped into 10 main themes: "The slogans of intimidation", "You need your family", "Save your homeland", etc [3,196]. The most effective in 1942 was the argument "Your family needs you." Sentimental topic intensified decadent moods of the enemy, in order to suppress the will of the Hitlerites as much as possible. The leaflet below shows a child against the background of letters to his father 
asking him to return home. This is one of the few leaflets, of which literal translation is kept in the State Social and Political Library of the Russian Federation [5]. In the text of the leaflet, the theme of the call to class consciousness and even to some justification of the Hitlerites "deceived" by their enslavers. A stamp is placed on the leaflet, as a pass to be imprisoned. The whole text is composed in the spirit of Soviet propaganda and it would hardly be understandable for the Germans. However, the theme of the child, the son who writes to his father and encourages him to return home, has become the main semantic content. The words that the farewell kiss of the wife and child have not yet cooled on the lips of the Hitlerite, the warmth of the home heart no longer heats one. Because he is on the vast expanses of Russia and freezes in his gray army overcoat. This first paragraph is the main one, it carries a semantic continuation in the child's bewilderment that his dad does not return. After reading these words, you begin to look at the image of the boy in a new way. With a thin neck, with a neat haircut, the boy looks directly at the leaflet reader. His face is not childishly distorted from bewilderment. Why did his father leave him and why does not he come and will he come at all?

Such a story is remembered and supplemented by the own experiences of each father who is at war, about the possible orphanhood of his children. The possible future of their children the Hitlerite started to associate with his own fate in this war. The doubts that arose with the German serviceman became the basis for a possible decision to surrender. What is the role of the child's image in this leaflet? The kid is a victim of circumstances that are caused by his father's participation in the war. This leaflet creates a kind of hopeless situation for the German soldier on the territory of the USSR. A professional soldier who has experienced so many victories, conquering a vital space for the future of Germany, can leave his own son as an orphan. And as a way out of this situation - the offer to surrender. Only in this way it was possible to save lives and later return home.

The next copy of the leaflet is rather laconic. A crying defenseless toddler is depicted on the background of his father's corpse. The leaflet is specified by a minimum of characters, a limited color and a short phrase: "Remember about your child."[11] This leaflet is made in the technique of family photos-postcards. However here is not a laughing happy baby depicted, but a tearful and unhappy orphan. The child did not fully understand the depth of his grief. But his tears are sincere because he will not see his native person. The look of a crying baby looking at the reader of the leaflet can not leave anyone indifferent. The authors of the leaflet counted on the fact that every German would have a sense of responsibility towards his children, which would have to be compared with the need to fulfill his soldier's duty in a war that no longer seemed victorious.

Such life-like moments are remembered and immediately overgrown with associations of their own experiences and memories. This image of a child who was a victim of circumstances caused by the death of his father in the war, could not leave indifferent. At some point in the perception of this image, some personal characteristics, such as hair color, haircut, are erased. Only a glance remains expressing suffering and desperation. The authors of this leaflet could have accurately conveyed the essence of the possible experiences of well-trained and ideologically trained Nazi soldiers.

The next leaflet also used the story of orphaned children [16]. Against the background of a German death notification, the elder brother is telling with tears to a small child, that they will not see their father anymore. Accurate, well-dressed children, still from a happy family life personified family comfort and a successful continuation of the family for every Nazi. This leaflet is interesting for special ways of creating the image of a suffering child. We hardly see the face of the older boy. And only a brilliant tear with wet eyelashes convey the whole tragedy of the ruined childhood and the inevitability of accepting a new, adult life with its hardships and cruelty. This little boy, who became a victim of war, as an orphan, now must take care of the younger child in the family.

Leaflets with sentimental subjects were quite effective. Specialists of the 7th Division of the Main Political Administration of the Red Army developed a series of stories on the topic "Vater ist tod" (Papa was killed). The head of the Soviet Information Bureau, Alexander Shcherbakov, recalled the following story: "I was told about the leaflet "Fater Ist Tod!"- its action surpassed all expectations. I was told that there was no prisoner who did not mention it and that many German soldiers, raising their hands, held this leaflet as a pass to the captivity [1]. Features of artistic representation of children of German soldiers, as victims of war, are due to their indirect participation in the military confrontation. Precaution of their future and prosperous present had to become the main motivational component that shaped the attitude of the Nazis towards their own role in the war.

Very different methods were used by Soviet visual specialists in creating the image of a victim of Soviet children. If in the first case the children remained orphans, but they continued to live in a relatively safe environment, the fate of total destruction and enslavement was specifically for the Soviet children. A child is a symbol of procreation, a symbol of the future. When they destroy a child, they destroy the future. And in this case for Soviet artists, universal concepts were combined with personal perceptions about the role of each person in the future of society.

What mark can one make on the world? The civic role of the head of the family, breadwinner, and educator of children was connected with the socially significant role of the defender of his motherland and the defender of the future of his country. All this found expression in the visual style used in the creation of Soviet leaflets and posters from the Second World War. Soviet children were victims of the enemy, who perceived them as a target for destruction or enslavement. In accordance with the National Socialist ideology, the population of the USSR was assigned an unenviable part of total destruction without a special choice of humane ways of dealing with it. The topic 
of the threat to family members was one of the main ones in raising the morale of the Red Army. Typically, these posters or leaflets depicted children whose lives were cut off or threatened with death.

Such images were laconic and accompanied by short slogans - appeals. So, on the poster of V.S. Ivanov "Death to the child-killers!" a girl is depicted who only collected flowers and was killed by a Hitlerite [7]. White flowers, white dress, and bow on her head speak of youth, purity, and harmony with the beautiful. Her blood bloated both flowers and earth. This symbolic image of the loss of the future, beautiful and deeply intimate to every Soviet soldier, became a call for revenge. The enemy's image is also symbolic. It is presented in the form of a huge boot with a bloody sole and a swastika. Minimum of color, minimum of symbols and deep semantic connotation. The slogan itself is also written in red. The color of the enemy's blood, which he must pay for his atrocities.

On another poster made by P. Karachentsov with the call "Death to murderers!"[8] Also used symbolic elements in the image of the enemy. Footprints with a swastika and the bloody body of a dead girl. As judged by the scattered books and maps, she was a student. A calendar sheet with the date of the beginning of the war. Reflection of sunlight in the window aperture, sunlit face of the victim, frozen in misery. The inscription-appeal is written as though by blood. In this image, there is light and darkness as the embodiment of the struggle between good and evil. Young girl as the embodiment of youth, the educated future of this country, was the victim of a gross violation of the right to life.

This theme in different variations was used by artists to create motivation to destroy the enemy, to force him to bear the punishment for the death of children. So in the poster of V. Ivanov, the Baltic Fleet fighter is depicted [17]. Against the background of historical buildings in Leningrad, the fighter holds the body of the murdered girl. His face is full of calm determination to take revenge. As in the previous poster, the girl is depicted as the embodiment of childlike innocence and the blood that has stained white clothes is a symbol of martyrdom. This image has a perspective and a more artistically expressed semantic depth. In the background, there are elements of significant buildings that reflect the millennial history of the city and the country. According to the color scheme, these elements are combined with the image of the victim of the enemy and in the center there is a powerful but not grotesque stature of a warrior of the Baltic Fleet. In one hand, there is an assault riffle and a cap, which he took off, paying tribute to the dead girl, with the other hand he supports the bloody child figure. Merciless revenge on the Hitlerite infanticide - the meaning of the call-inscription and the meaning of his armed struggle with the enemy.

In another poster of M. Nesterov "Dad, Kill the Germans!" the theme of the need for revenge for the members of the families-victims of the enemy is already more complete[6]. It's about a mother and a baby. Against the background of the burning village, we see the corpse of a woman and a discouraged and depressed child standing in the foreground,. He understands that the mother is no longer there, he is not at home, and he is alone in the horror of enemy arbitrariness. The figure of a defenseless child in a white shirt again sends the viewer to the innocence and fragility of the life of the future children and the country as a whole. They ask for protection. In this case, the appeal to the fathers and with a specific proposal for action. Kill the one who orphaned this innocent child, who was at the epicenter of evil and horror.

The same theme but in a different imaginative solution is embodied by the artist L. Golovanov [10]. The executed mother and child which were stepped over by the beast-like Hitlerite with the steaming from using weapons. All this against the background of the glow, the destroyed buildings, and the gallows. And, it is clear that on one of the gallows the body of a woman. Insult on the defenseless, the destruction of those who cannot resist that's the essence of the Germans, expressed on this poster is grotesque manner. This visual format is of a large size since it is made using small details. It must be carefully considered. The figures of the executed mother and child in the foreground are very symbolic. The image of a woman, despite the tragedy of the situation, is distinguished by elegant lines of the chin and neck. The position of her figure is too somewhat traditional for such subjects. The artist used the traditional method of showing a seductive female body to receive a half-turn. The Hitlerite looked at her in the brutal and at the same time lascivious way. What does the author want to say? After all, this woman is young, attractive, she was someone's lover, wife. With her were the future of the family and the wellbeing of the child. And now all this is destroyed, the whole future is trampled. The image of a murdered child with touching curly hairs and a plump hand speaks of the tragedy of the future not only of this family but of the whole society. Above them, the central figure rises the German enemy with a swastika and animal fur on his hands. Swastika on the sleeve as a target for defeat. The artist, as it were, says: "This is evil, this is the one who kills everything in its path. Here is the one who needs to be destroyed and avenged for the desecrated honor and selected life of native people. " Every small detail of the image only strengthens the formed motive for action. The Soviet soldier understands that there, in the rear, his families were left defenseless. And if he does not destroy the enemy, then his relatives will suffer the same fate. As a supplement to the viewer's thoughts, a quatrain is written in small print: "For the honor of the wife, for the life of the children, for the happiness of their homeland, for our fields and meadows, kill the invader-enemy!" Slogans-appeals were not only a verbal expression of the spectator's feelings, the conclusion about what to do in this situation. Destroying the enemy is the only way to protect your relatives.

The theme of the mother and child-victims of the war in the next poster is expressed somewhat differently[13]. A woman with a weapon in her hands calls for revenge for the murdered child. As if sleeping in the foreground baby in white socks and shirt. And only a stream of blood from the temple testifies the terrible atrocity in relation to him, to all children, defenseless before the enemy. In this image, the woman is no longer in the role of a victim, but in the 
role of an avenger who took up arms and is ready to destroy the Hitlerites. Her fluttering hair fades with the flames of fire in the background. There is already no grace in the female figure. On the contrary, one can see a somewhat crude image of a mother ready for anything for vengeance.

At the bottom of the poster, a slogan is printed: "We will destroy the fascist cannibals!" The following poster uses the slogan: "Death to the German murderers!"[9] The artist draws the viewer's attention to the hijackings of Soviet citizens. In the background there is a van into which protesters are pushed. Their indignations are expressed by dynamic gestures. In the foreground there is a woman trying to protect her child from a bony, spider-like arm of the Nazi. Warmly dressed Germans and in-home clothes of their victims. This contrast indicates that people are torn from their habitual environment and forced to obey the Swastika by car and on the sleeve are combined with a black background, with the darkness that envelops the entire life of these unhappy people.

On the next poster, there is not a mother only as a victim depicted but also the elder sister with the younger child [14]. Two Nazis are standing over the body of the murdered woman and watching over the running girl - a teenager with a younger child. Crying, the despair and the deep sorrow that befell these children are in sharp contrast to the quiet confidence of the marauding Germans who are giving away their victims. The artist conveyed the mocking tone of the Hitlerites who undressed the children running away in winter. The enemy grins at the fact that these unhappy people cannot escape far. The image itself is supplemented by the poetic history of this tragedy. The German beasts have reached your house. They took away all the belongings, pushed your wife ... with the children. They ran along the street. But then your wife ... the German bullet struck down to death ... The eldest daughter ... and son ... cried. But your wife did not hear them anymore. In large font, there is an inscription-appeal: "The revenge on the German dogs!"

This theme is repeated in another poster depicting the theft of the civilians by the Nazis. The last woman tries to resist, but the German blocks her way. Her children remained. The eldest sister presses the younger child to herself with horror and appeals for the help. The inscription on the poster says "Stalk, Comrade Red Army!"[12] Statures of children victims of German tyranny are depicted in the corner. Central is the prospect. People leaving under the escort of the Hitlerites. The shadows envelop them. Broken trees and gloomy figures of enemy soldiers. Everything speaks of the inevitability of physical destruction and the trampling of the basic human right to life. The inscription is the voiceover of the cry of a teenage girl. Posters are designed to cause a strong sense of hatred in those warriors whose families are or may be in danger. This was a powerful message to the formation of a clearly conditioned motivation for action.

In the work on visualistic Soviet artists used different artistic techniques. But they were all called upon to form a deep hatred of the Red Army men to the enemy and in the conditions of momentary hopelessness. Any man in the war understands that his loved ones remain unprotected in the territory occupied by the enemy. The only way to protect wives and children was to destroy the Germans. Therefore, the calls: "Revenge", "Capture" are powerful messages to the merciless destruction of the enemy. In addition to hand-drawn images, posters used photos. In the poster below, "A soldier, save me from slavery!" used a combination of a monochrome picture with the drawing of details[4]. In monochrome photo images, the essence of things is revealed deeper. The attention is drawn to the most important. In this image, shapes and lines are clearly visible. Particular emphasis is placed on rhythm, light and shade and structure. On this poster, everything is laconic in its tragedy. In fact, the last call, the last look of the child, which was destroyed by the German concentration camp machine. This view is from there, from where they do not return. For every Red Army soldier, this was the sacrificial image of his own child in a ruthless war.

The most famous work of the artist V.B. Koretsky "The Red Army Soldier, Save!" was made in the same style around the image of the mother and her child, there is a glow - a symbol of holiness[15]. It is worth paying attention to the fact that the images of women victims of the war in Soviet posters were of a somewhat religious nature. Appeal to the archetypal images of Christian martyrs made these images similar to icons. Despite the fact that the USSR was a country with communist ideology, during the war the theme of the Christian greatness of the struggle between good and evil was again raised to the level of ideological narrative. Victory had to be achieved by any means. Iconographic traditions were often used in the Russian art . Here is how his creator recalls the work on this poster: "In the poster of 1942" The Red Army Soldier, Save! "I was looking for a solution that would help me express the amazing sense of inflexibility and perseverance along with woman's desperation that distinguished Soviet people leading just a people's war. Working on sketches for this poster, I, first of all, tried to refuse from everything superfluous, random, rhetorical. In the first version of the poster, a woman was shown, who shielded her children from the bayonet aimed at them.

Against the background of the poster there are the flames. In the second variant - a woman holding a child in her arms, angrily raised her fist against the fascists. Against the background of the sheet burning huts were painted. However, both variants did not satisfy me, because the images did not have the proper psychological sharpness and generalizing power. I wanted to concentrate the viewer's attention on the faces of the woman and the boys clinging to her chest. It was necessary to achieve such expressiveness of the mother's eyes that the viewer could see both contempt and hatred of the enemy in them. I also tried to reflect these feelings in the eyes of the child. His gaze was supposed to complement the mother's gaze. It was thought that the mother and child were not to look at the bloody bayonet, but at the enemy[2].

The faces of a woman and a boy, a smooth dark background, a call, as if written with drops of blood flowing down from a fascist bayonet ... It seemed to me that all these figurative elements are important, necessary for an 
imaginative solution of a photographic poster that was supposed to be intelligible, understandable and effective. The success of the poster was determined immediately. The main political administration of the Red Army approved the sketches, then the originals. In August 1942 the poster was printed in the newspaper Pravda. Later this image was repeated many times.

In general, its circulation was over 10 million copies. The influence of this visual format was expressed in the letters of the Red Army. In a letter to the newspaper Pravda, Guard Captain I. Kuzmenko wrote: "Since the beginning of the Patriotic War with a small break, I have participated in the front, lost contact with my wife and two young sons. I appeal to thank V. Koretsky for the truth shown by him in this poster, forever left in my mind. I will put all my strength, give all my blood a drop for a drop to save many wives and children from slavery, from bullying, gallows ... I promise, not a step back with my people who are entrusted to me, but only forward. I ask you to post this poster in all the newspapers, and not only in newspapers, but in a large print run and in every corner in the city, village, military units, hang out on a visible place, so that many will remember their wives and children and take revenge on Hitler's mercilessly bandit barbarians ... We swore before the Motherland to avenge the enemy for the torment of our sisters, wives, and children, for the shed blood and tears. We will fulfill this oath. The enemy will be defeated and destroyed, and our mothers, sisters, wives, and children will be freed from the fascist yoke and enslavement.[5] " These lines of front-line letters are eloquent. They talk about the power of the exposure of poster art, about its mobilizing role.

Conclusions. At the front, hatred to the enemy was the most important condition for the combat capability of the Soviet troops, a powerful motivation for their readiness for self-sacrifice, for the battle not for life but for death. Almost every Soviet soldier had a personal attitude to the Hitlerite invaders. Many lost their relatives, their cities and villages were captured and destroyed, many witnessed the brutality of the enemy in the occupied territories themselves.

But these forms of agitation production were not meant for aesthetic pleasure. They called for concrete actions. For the troops of Hitler's Germany, there was a call for an end to participation in the war. The purpose of their manufacture and distribution among the personnel of enemy troops is demoralization of the enemy and motivation for certain actions.

The ideologists of the Red Army used the motives of family values for the soldiers of Hitlerite Germany. The main task is the moral disarming of the Nazi servicemen. Throughout the Second World War, the theme of retaliation was one of the essential in the agitation and propaganda activities of the political structures of the Red Army.

The best expression of such sentiments was the visual format. Leaflets and posters of the Red Army in the Second World War could be compared with non-combat weapons of mass destruction. Some of them could be considered as examples of fine art, although, very often they were printed on cheap paper and typographical flaws. For the Red Army, the image of women - mothers, sisters, wives were associated with the image of the Motherland.

The image of the child characterized the defenselessness and vulnerability of the future country and the future family of each soldier. That is, they were powerful stimulus for a selfless struggle with the enemy.

The most frequent themes for images that were to raise the spirit of Soviet soldiers were the following: raped and killed women with children crying beside their bodies. Images of women prisoners, children with distorted suffering faces behind barbed wire. Weeping and crying for protecting children. These images did not just inspire the struggle. They evoked hatred for the enemy and served as a powerful source of energy for the formation of a desire to revenge.

Thus, the image of war victims - women and children, usually the most vulnerable in the war, was used in propaganda activities to maintain the morale of the Red Army and to stop the resistance of the Nazis. Images with deep religious background were calculated on the archetypes of ideas about the struggle between good and evil for Soviet soldiers and the established canons of the family for the Hitlerites.

\section{תimepamypa}

1.Бурцев М. И. Прозрение. М.: Воениздат, 1981.320 с., 14 л. илл.- (Военные мемуары). URL: http://militera.lib.ru/ memo/russian/burtsev mi/index.html.

2. Корецкий В. Плакат сражается. М.: «Плакат», 1981 г. URL: http://tramvaiiskusstv.ru/plakat/spisok-khudozhnikov/item/176koretskij-viktor-borisovich-1909-1998.html

3.Политическая работа среди войск и населения противника в годы Великой Отечественной войны (1941-1945). М.: Воениздат, $1971.256 \mathrm{c}$.

4."A soldier, save me from slavery!" URL: www.google.com.ua/search?q=советские+листовки+вов\&tbm=isch\&tbs= rimg:CT8N1AZ_1P

5. "Dad, come home!" URL: http://agitka.su/index.php/ussr/520-centralshtab/belpartizan/beznomlbelshtab/6124-bel13.

6. "Dad, kill the German!" URL: www.google.com.ua/search?q=советские+листовки+вов\&tbm=isch\&tbs=rimg:CT8N1AZ_1P

7. "Death to the child-killers!" URL: www.google.com.ua/search?q=советские+листовки+BOB\&tbm=isch\&tbs=rimg:CT8N1AZ_1P.

8. "Death to murderers!" URL: www.google.com.ua/search?q=советские+листовки+вов\&tbm=isch\&tbs=rimg:CT8N1AZ 1P.

9. "Death to the German murderers!" URL: www.google.com.ua/search?q=советские+листовки+вов\&tbm= isch\&tbs= rimg:CT8N1AZ 1P.

10. "For the honor of the wife, for the life of the children, for the happiness of their homeland, for our fields and meadows, kill the invader-enemy!" URL: www.google.com.ua/search?q=советские+листовки+воB\&tbm=isch\&tbs=rimg:CT8N1AZ 1P.

11. "Remember about your child." URL: www.google.com.ua/search?q=советские+листовки+вов\&tbm=isch\&tbs=rimg:CT8N1AZ_1P.

12. "Stalk, Comrade Red Army!" URL: www.google.com.ua/search?q=советские+листовки+вов\&tbm=isch\&tbs=rimg:CT8N1AZ_1P.

13. "Take revenge! Destroy the fascist cannibals!" URL: www.google.com.ua/search?q=советские+листовки+вов\&tbm=isch\&tbs $=$ rimg:CT8N1AZ_1P. 


\section{Вісник Національної академії керівних кадрів культури і мистецтв № 2'2019}

14. "Take revenge on German dogs!" URL: www.google.com.ua/search?q=советские+листовки+вов\&tbm=isch\&tbs= rimg:CT8N1AZ 1P.

15. "The Red Army Soldier, Save!" URL: "www.google.com.ua/search?q=советские+листовки+вов\&tbm=isch\&tbs= rimg:CT8N1AZ_1P.

16. "We will no longer see our father, Hitler has taken his from us.". URL: www.google.com.ua/search?q=советские+листовки+ BOB\&tbm=isch\&tbs=rimg:CT8N1AZ 1P.

17. "Warriors of the Red Army and Navy, ruthlessly avenge Hitler's infanticide!" URL: www.google.com.ua/search?q=советские+ листовки+ вов\&tbm=isch\&tbs=rimg:CT8N1AZ_1P.

\section{References}

1. Burcev M. I. (1981). Prozrenie. Moskva: Voenizdat [in Russian].

2. Koreckij B. (1981). Plakat srazhaetsja. Moskva: «Plakat». Retrieved from: http://tramvaiiskusstv.ru/plakat/spisokkhudozhnikov/item/176-koretskij-viktor-borisovich-1909-1998.html [in Russian].

3. Politicheskaja rabota sredi vojsk i naselenija protivnika v gody Velikoj Otechestvennoj vojny (1941-1945). (1971). Moskva: Voenizdat [in Russian].

4."A soldier, save me from slavery!". Retrieved from: www.google.com.ua/search?q=советские+листовки+вов\&tbm=isch\&tbs =rimg:CT8N1AZ_1P [in English]. English].

5. "Dad, come home!". Retrieved from: http://agitka.su/index.php/ussr/520-centralshtab/belpartizan/beznomlbelshtab/6124-bel13. [in

6. "Dad, kill the German!". Retrieved from: www.google.com.ua/search?q=советские+листовки+вов\&tbm=isch\&tbs= rimg:CT8N1AZ_1P[in English].

7."Death to the child-killers!". Retrieved from: www.google.com.ua/search?q=советские+листовки+вов\&tbm=isch\&tbs= rimg:CT8N1AZ_1P. [in English]. "Death to murderers!". Retrieved from: www.google.com.ua/search?q=советские+листовки+вов\&tbm= isch\&tbs= rimg:CT8N1AZ_1P. [in English].

8. "Death to the German murderers Retrieved from: www.google.com.ua/search?q=советские+листовки+вов\&tbm=isch\&tbs =rimg:CT8N1AZ_1P. [in English].

9. "For the honor of the wife, for the life of the children, for the happiness of their homeland, for our fields and meadows, kill the invader-enemy!". Retrieved from: www.google.com.ua/search?q=советские+листовки+вов\&tbm=isch\&tbs=rimg:CT8N1AZ_1P. [in English].

10. "Remember about your child." Retrieved from: www.google.com.ua/search? $q=$ =оветские+листовки+вов\&tbm= isch\&tbs= rimg:CT8N1AZ_1P [in English].

11. "Stalk, Comrade Red Army!". Retrieved from: www.google.com.ua/search?q=советские+листовки+вов\&tbm= isch\&tbs= rimg:CT8N1AZ 1P [in English].

12. "Take revenge! Destroy the fascist cannibals!". Retrieved from: www.google.com.ua/search?q=советские+листовки+вов\&tbm= isch\&tbs= rimg:CT8N1AZ_1P [in English].

13. "Take revenge on German dogs!". Retrieved from: www.google.com.ua/search?q=советские+листовки+вов\&tbm= isch\&tbs=rimg:CT8N1AZ_1P [in English].

14. "The Red Army Soldier, Save!". Retrieved from: "www.google.com.ua/search?q=советские+листовки+вов\&tbm=isch\&tbs= rimg:CT8N1AZ_1P [in English].

15. "We will no longer see our father, Hitler has taken his from us.". Retrieved from: www.google.com.ua/search?q=советские+ листовки+вов\&tbm=isch\&tbs=rimg:CT8N1AZ_1P [in English].

16. "Warriors of the Red Army and Navy, ruthlessly avenge Hitler's infanticide!". Retrieved from: www.google.com.ua/ search?q=советские+листовки+ вов\&tbm= isch\&tbs=rimg:CT8N1AZ_1P [in English]. 